\title{
Oikoumene ou um trajeto pela casa comum: origens do ecumenismo
}

\author{
Oikoumene or a journey into the common house: \\ origins of ecumenism
}

\author{
Daniele Rocha Saucedo
}

\section{Resumo}

O presente artigo discute as origens do ecumenismo, propondo uma síntese que se inicia na etimologia do termo e chega à América Latina e ao Brasil. Para tanto, faz uma leitura e discussão a partir da obra do autor Elias Wolff, "Caminhos do Ecumenismo no Brasil". Para alcançar o objetivo de apresentar um panorama do surgimento do ecumenismo, recorre ao artigo de Zwinglio M. Dias, que trata do movimento ecumênico, sua história e significado em escala universal. Trata-se aqui, portanto, de uma proposta de revisão bibliográfica. O ecumenismo é um tema de importância indiscutível para a Teologia, a ser pesquisado e desbravado por estudiosos, teólogos e historiadores. Alguns elementos importantes foram apontados neste artigo com a intenção de suscitar futuras pesquisas. Além de instigar reflexões e lançar um olhar especial no âmbito da história do ecumenismo. Tema importante nas discussões que abramgem a teologia e as relações com outras áreas do conhecimento.

Palavras-chave: Ecumenismo. História. Brasil.

\begin{abstract}
This article discusses the origins of ecumenism in Brazil, proposing a synthesis that begins with the etymology of the term and reaches Latin America and Brazil. In order to write it, we performed a reading and had a discussion on the work named paths of ecumenism in Brazil by Elias Wolff. In order to reach the goal to present an overview of the appearance of ecumenism, we resorted to Zwinglio M. Dias text that deals with the history and meaning of the ecumenical
\end{abstract}


movement on a universal scale. Therefore, we have here a proposal for a literature review of indisputable importance for Theology, a subject to be researched and pioneered by scholars, theologians and historians. Some important elements were mentioned in this article with the intent to inspire future research. In addition to instigating reflections and taking a special look at the history of ecumenism. An important theme in discussions that cover theology and relationships with other areas of knowledge.

Keywords: Ecumenism. History. Brazil.

\section{Introdução}

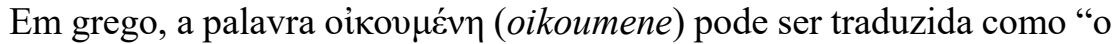
mundo habitado"; nela, o elemento central é "oikos", "casa", que evoca compartilhamento, convivência e reconhecimento entre semelhantes. Transposta para o ambiente das religiões, oikoumene gerou "ecumenismo", termo associado, pastoralmente, à unidade das igrejas cristãs. Neste artigo, buscaremos trazer uma síntese desse trajeto pela "casa comum", ou melhor, do ecumenismo, desde sua origem até sua chegada à América Latina e ao Brasil.

Em seu caminhar, o movimento ecumênico avançou de maneira mais incisiva, em especial na América Latina, a partir dos anos 1960. O Cardeal Cicognani, no decorrer da segunda sessão do Concílio Vaticano II, afirmou: "a Igreja Católica é ecumênica desde sua origem". ${ }^{1}$ Uma Igreja que mantém a unidade na catolicidade poderia, enfim, perceber-se ecumênica. A discussão, por certo, não se encerrou e não se encerra aí. Como observava Dom Javierre, "a Igreja não poderia ser considerada ecumênica, porque busca pinçar nas suas declarações oficiais uma grande quantidade de matizes de orientação francamente antiecumênicas". ${ }^{2}$

Para compreender a origem e o significado do termo ecumenismo é preciso, portanto, ir à sua raiz e esboçar um pouco de sua história. Sair de seu nascedouro, entre os gregos, e chegar ao momento em que ele começa a ser utilizado entre os cristãos de diferentes Igrejas, e no sentido que a Igreja Católica passa aceitar a partir do Concilio Vaticano II.

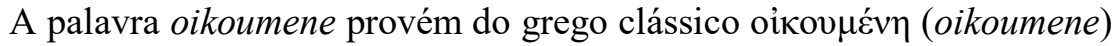
e se relaciona, na sua origem, à morada (oikos), ao assentamento, à permanência

\footnotetext{
${ }^{1}$ JAVIERRE, A., La Unión de las Iglesias, p. 17.

2 JAVIERRE, A., La Unión de las Iglesias, p. 17-18.
} 
e ao mundo habitado (he oikomene ge). Passou ao latim como oecumenicus, tendo um sentido de "coisa geral, universal". Foi assumida pela comunidade cristã e ganhou importância e significado diferenciados no contexto da religião nascente, no percurso da Igreja, em suas divisões e no contexto atual.

Para descobrir essa importância e significado, utilizamos o método descritivo. Teremos como referência as obras Movimento Ecumênico: História e Significado, do teólogo Zwinglio M. Dias, que apresenta, nessa perspectiva, as iniciativas ecumênicas a partir de meados do século passado, e também a obra Caminhos do Ecumenismo no Brasil, do teólogo Elias Wolff. Ambos os autores podem ser vistos, no presente contexto, como complementares, na medida em que o primeiro aborda a "jornada geral" do ecumenismo, desde sua origem - mas, especialmente, em seu contexto cristão - até sua chegada à América Latina, enquanto o segundo foca sua atenção no caso brasileiro.

Em sua obra, Zwinglio M. Dias se refere a uma citação do historiador Lucien Febvre que nos ajuda a ilustrar nossa reflexão. Ao discorrer sobre Lutero, Febvre escreve:

Na noite de 27 de junho de 1538, o grande reformador jantava em Wittemberg com seu companheiro de lutas e disputas, o doutor mestre Felipe Melanchthon. Os dois homens estavam tristes. Falavam do futuro. Lutero interrogava: "Quantos mestres diferentes seguirá o próximo século? A confusão será total. Ninguém se deixará governar pela opinião ou a autoridade de outro. Cada um procurará ser seu próprio Rabi (mestre): como já é o caso de Osiander, de Agrícola. [...] e então quantos escândalos enormes, quantas dissipações! $\mathrm{O}$ melhor seria que os príncipes, por meio de um Concílio, procurassem prevenir tais males; mas os papistas não aceitariam jamais isto; têm tanto medo à luz [...]". Por sua vez, Melanchthon respondia no mesmo tom: "Oh! queira Deus que os príncipes e os Estados possam encontrar num Concílio uma fórmula de concórdia para a doutrina e as cerimônias, estabelecendo uma proibição para ninguém se afastar dela temerariamente, para escândalo do próximo. Sim, é três vezes lamentável o rosto de nossa Igreja mascarada sob tal capa de debilidades e escândalos!"’3

Com a Reforma Protestante e seus representantes, a partir do século XVI, rompe-se fragorosamente uma unidade cristã até então mantida a duras penas pela Igreja Católica no Ocidente. Grande havia sido, aliás, o trauma da outra

\footnotetext{
${ }^{3}$ FEBVRE, 1956 apud DIAS, Z. M., O Movimento Ecumênico, p. 128-129.
} 
divisão, o chamado "Cisma do Oriente", que levou à separação das Igrejas Católicas do Oriente e do Ocidente cinco séculos antes.

Muitos foram os fatores - teológicos e políticos - que impulsionaram a Reforma: a venda das indulgências; a desmoralização dos intermediários do clero; o nascimento do Estado moderno, com suas demandas de independência, jurisdição, normas, patrimônio e língua escrita que não fosse o latim; as diferenças locais; o surgimento da imprensa, com a publicação dos textos bíblicos nos idiomas dos novos Estados; a busca de uma nova ética religiosa; o movimento luterano; e novas ideias teológicas. Esses fatores, vale observar, foram objeto de inúmeros artigos e dossiês publicados em vários países no ano de 2017 (e nos anos seguintes), quando se comemorou os 500 anos da Reforma. No Brasil, podem ser citados os dossiês produzidos em revistas como a "Horizonte", da PUC Minas, e a "Teocomunicação" da PUCRS. ${ }^{4}$

Observa-se, pois, que as razões para o rompimento da comunhão extrapolam as motivações religiosas e agregam elementos de caráter cultural e político que, muitas vezes, se sobrepõem aos argumentos propriamente teológicos. Lutero e Melanchthon (Fig. 01) apenas antecipavam os enormes conflitos - e os avanços, por certo - que estavam chegando.

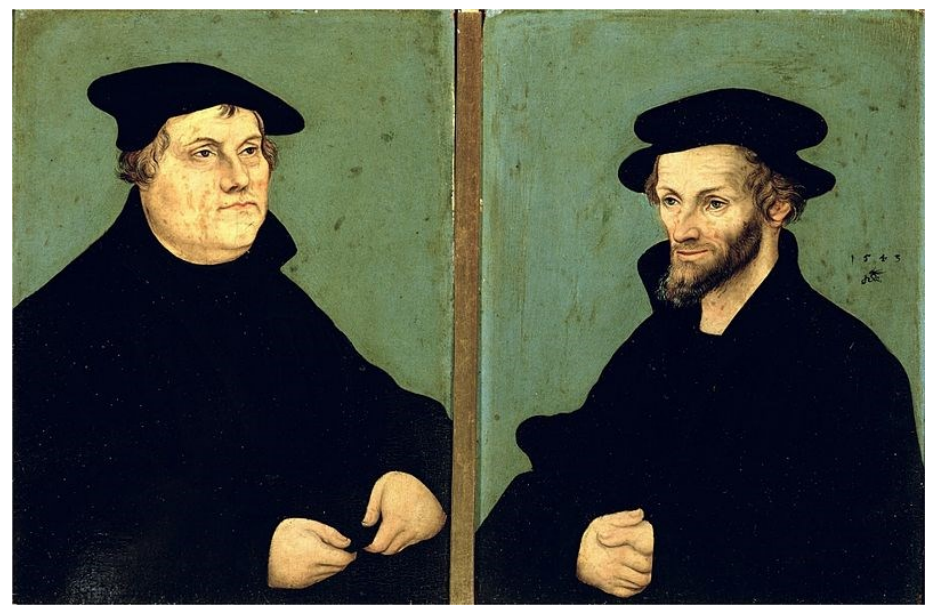

Figura 01 - Retratos de Martinho Lutero (1483-1546) e Phillipi Melanchton (14971560), de Lucas Cranach, o Jovem (1558)

\footnotetext{
${ }^{4}$ HORIZONTE - Revista de Estudos de Teologia e Ciências da Religião (PUC Minas), Dossiê "Lutero e a Reforma: 500 anos", v. 14, n. 44, out./dez. 2016; TEOCOMUNICAÇÃO (PUCRS), Dossiê "500 anos da Reforma Luterana: heranças e desafios", v. 49, n. 1, jan./jun. 2019.
} 


\section{Oikoumene: a "casa comum" e a unidade cristã}

A raiz primeira da qual provém outros termos é oikos, casa, lugar em que se mora, espaço habitável e habitado. Oikoumene, significa, assim, o mundo habitado em que coexistem diferentes povos, com diversidade de línguas e culturas. "Mas em seu sentido primeiro, seria a terra habitada pelos helênicos", isto é, por um povo civilizado que oferecia uma cultura aberta a todos, dando essa unidade básica de cosmovisão exigida por uma civilização autêntica. ${ }^{5}$

Em muitas civilizações, a palavra "casa" se reveste de um poderoso significado, que vai além de uma semântica instrumental mais estrita. "Casa", enfim, reflete muitas coisas, sentimentos, pertencimento. É o que se percebe na língua grega e na Grécia (Fig. 02), civilização formada por cidades-estado que, a despeito de sua independência, orgulho e nativismo, conseguiam se perceber como uma unidade algo que já se vê desde a "Ilíada" (em que reinos gregos se unem para lutar contra troianos) e que ganha relevo, por exemplo, nos enfrentamentos entre gregos e persas. Navarro elenca outros termos gregos clássicos associados a oíkos:

- oikos: casa, vivenda, aposento, povo.

- oikeiotês: relação, aparentado, amizade.

- oikeo: habitar, coabitar, reconciliar-se, estar familiarizado.

- oikmwmeô (verbo): administração, encargo, responsabilidade da casa.

- oíkownene: terra habitada, mundo conhecido e civilizado, universo. ${ }^{6}$

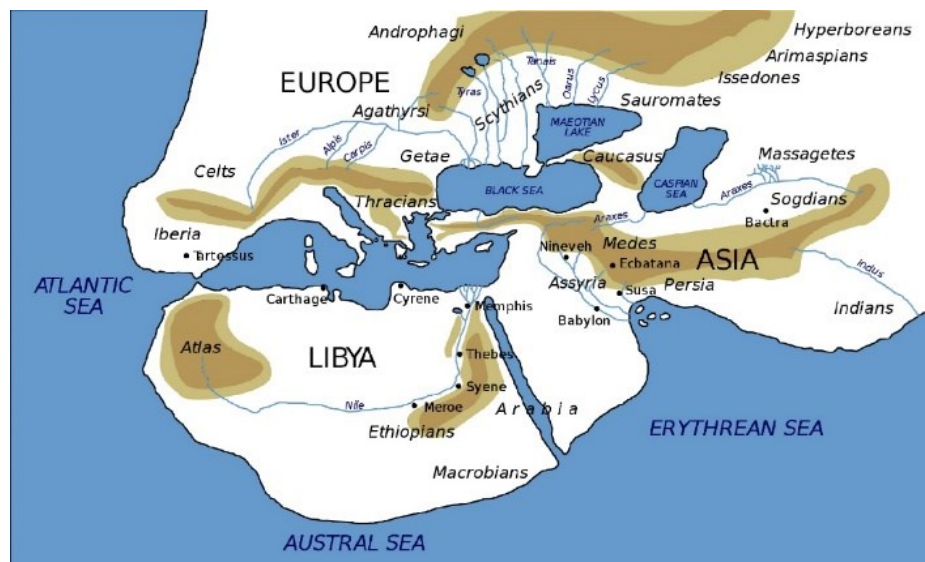

Figura 02 - Uma representação moderna do "ecúmeno" descrito por Heródoto no século V a.C.

${ }^{5}$ NAVARRO, J. B., Para compreender o Ecumenismo, p. 10.

${ }^{6}$ NAVARRO, J. B., Para compreender o Ecumenismo, p. 10. 
Logo, oíkos pode ser a casa onde se mora ou o local onde se desenvolve a família. A família e o lugar comuns ou tornados comuns por algum fator. Entre os gregos, por exemplo, esta condição era dada pelo idioma, pelas trocas comerciais e pelo "mar comum", compartilhado, que unia diversos povos. A própria "Pax Romana", na qual, sob o jugo das armas, leis e estradas, muitos povos passaram a viver sob a influência romana, é um símbolo de ecumenismo.

O termo oikoumene aparece, também na literatura bíblica, como em At 11,28 , que recupera o antigo sentido de mundo ou do império romano (Lc 2,1). $\mathrm{Na}$ Carta aos Hebreus $(2,5)$, observa-se: "Não foi a anjos que ele sujeitou o mundo futuro, de que estamos falando". Paulo enfatiza o caráter transitório da presente oikoumene, para afirmar a chegada iminente de uma nova e transformada oikoumene, proposta por Jesus Cristo. Assim, a oikoumene neotestamentária apresenta-se "como um processo em contínuo desenvolvimento que se inicia como 'a terra habitada', que vai se tornando 'lugar habitável', a casa em que cabe toda a família humana"7 e a resposta do homem diante do chamado de Deus é como o germe de uma nova oikoumene, que vem como obra de Deus em colaboração humana.

Traços do termo ecumenismo já estão presentes na Igreja primitiva, com os padres da Igreja. Nos concílios de Nicéia (324) e de Constantinopla (381), a palavra oikoumene representa a Igreja universal e é utilizada na denominação de concílio ecumênico e, ainda, "para designar as doutrinas e usos eclesiais que são aceitos como norma de autoridade e dotados de validade universal em toda a Igreja Católica". ${ }^{8}$

Mais tarde, o termo oikoumene será atribuído também aos "credos ecumênicos", os dos apóstolos, o de Nicéia e o de Santo Antanásio. A seguir, refletiremos sobre o desenvolvimento histórico desse termo.

\subsection{Uma síntese de Oikoumene: do uso sociopolítico à identidade cristã}

É impossível, no escopo de um artigo como este, oferecer ao leitor um panorama amplo do ecumenismo. Assim, buscaremos trazer uma síntese que colabore para um melhor desenvolvimento do tema, focado na trajetória do ecumenismo até sua chegada às terras latino-americanas e brasileiras.

Julio de Santa Ana, em "Ecumenismo e Libertação", apresenta o desenvolvimento da oikoumene a partir das quatro dimensões da existência humana. Ele sustenta a ideia de que, na história, os escritores gregos clássicos

\footnotetext{
${ }^{7}$ NAVARRO, J. B., Para compreender o Ecumenismo, p. 10.

${ }^{8}$ NAVARRO, J. B., Para compreender o Ecumenismo, p. 10, grifo do autor.
} 
utilizaram a expressão para opor a realidade do mundo grego aos espaços não conhecidos por seus habitantes. O termo passou a ser usado com esse significado no final do século IV AEC, a partir das conquistas de Alexandre Magno, que estendeu a oikoumene grega (o mundo helenizado) do Mar Egeu e do Egito até as margens do rio Indo, em um território atualmente ocupado por Afeganistão e Paquistão. ${ }^{9}$ Dessa forma, o conceito de oikoumene ganha força, também, em sentido geográfico. Segundo Zwinglio M. Dias:

O processo de helenização iniciado por Alexandre Magno abarca diferentes povos e culturas, como os egípcios, babilônios, sírios, semitas, caldeus, persas etc. E nessa diversidade de culturas, impunha-se, portanto, o estabelecimento de algo que pudesse dar unidade a todas estas nações e povos tão diferentes. Surge, então, o ideal do homem helênico como um elemento unificador e totalizante. ${ }^{10}$

Na continuidade de sua análise, o autor afirma que o helenismo trouxe consigo, entre o séc. III AEC até o domínio de Roma sobre o mundo mediterrâneo (séc. II EC), o conceito de um indivíduo cosmopolita que seria o próprio representante da verdadeira humanidade. Surge, desse modo, a oposição entre "helênico" e "bárbaro", entre civilizado e inculto; de início, o mundo da cultura correspondeu à oikoumene. Seria esse o conceito cultural do significado de oikoumene.

Para o entendimento do significado político do termo oikoumene, Julio de Santa Ana recorre à explicação do poder grego no mundo antigo após a morte de Alexandre, o desmembramento do território em satrapias e a ascensão de um novo poder. Segundo Santa Ana, esse poder foi Roma:

A esse período corresponde um novo sentido da palavra oikoumene. Já vimos como essa palavra teve primeiro uma conotação geográfica e em seguida cultural. Quando o Império Romano impõe seu poder sobre as terras que circundam o que eles chamavam "Mare Nostrum", o termo adquiriu uma dimensão política, que complementa a compreensão cultural, helenística, que havia sido dada a esse vocábulo. ${ }^{11}$

Temos, então, a recepção do termo pelo Cristianismo, religião nascida, de resto, no interior da oikoumene romana em seu momento de maior expressão.

\footnotetext{
${ }^{9}$ DIAS, Z. M., O Movimento Ecumênico, p. 131.

${ }^{10}$ DIAS, Z. M., O Movimento Ecumênico, p. 131.

${ }^{11}$ SANTA ANA, 1987 apud DIAS, Z. M., O Movimento Ecumênico, p. 132.
} 
A ideia surge nos três sentidos acima referidos no Novo Testamento e, como oikoumene, em nada menos do que quinze passagens:

Recuperando em algumas delas o sentido de mundo (At 11.28), de cultura helênica (Rm 10.18; Hb 1.6; Ap 12.9), de Império Romano (Lc 2.1). O termo é introduzido na literatura eclesiástica quando o Concílio de Constantinopla (em 381) refere-se ao Concílio de Nicéia (em 325) como um concílio ecumênico. ${ }^{12}$

\subsection{A Constituição do Ecumenismo}

Como vimos, oikoumene passa a ser usado e se consolida na literatura eclesiástica a partir dos primeiros quatro concílios da Igreja - Niceia (325 EC), Constantinopla (381), Éfeso (431) e Calcedônia (451), ${ }^{13}$ focado especialmente na unidade das igrejas cristãs de então. Em Calcedônia, o Concílio realizou a emancipação de Jerusalém da jurisdição de Cesareia e lhe deu o quinto lugar entre as grandes sedes.

A partir de então, cinco grandes sedes da Igreja - marcos da oikoumene - eram mantidas em honra especial. Uma ordem de precedência foi estabelecida de forma decrescente: Roma, Constantinopla, Alexandria, Antioquia e Jerusalém (Fig. 03).

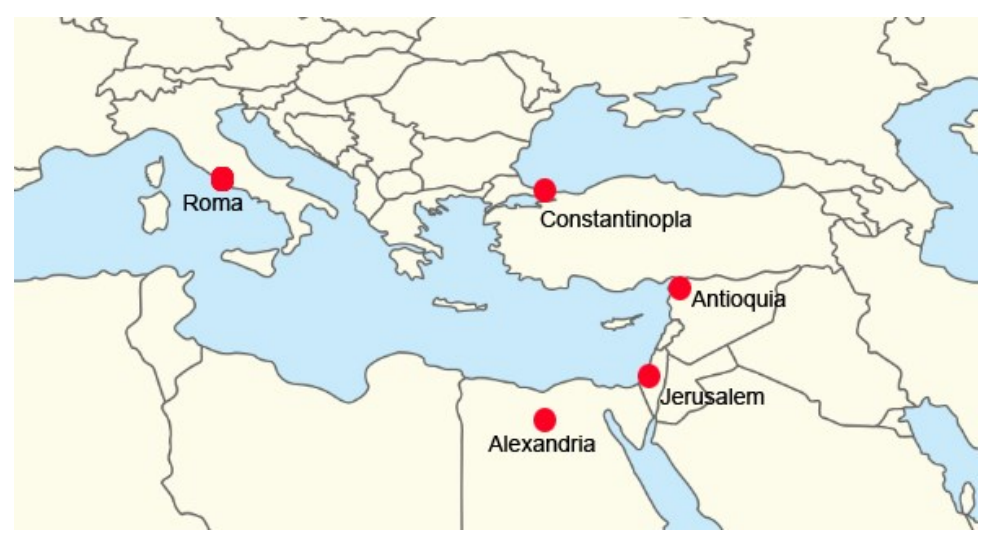

Figura 03 - As cinco sedes da Igreja estabelecidas pelo Concílio de Calcedônia (451 EC)

12 SANTA ANA, 1987 apud DIAS, Z. M., O Movimento Ecumênico, p. 132.

${ }^{13}$ NAVARRO, J. B., Para compreender o Ecumenismo, p. 9-10. 
Será somente no século XVII, após a Reforma Protestante e o novo fracionamento institucional da Cristandade europeia, que o significado religioso de "ecumenismo" vai ganhar sentido. Um sentido de unidade que se faz presente e ganha relevo, inclusive, na contradição, ou seja, por conta da perspectiva de separação.

Júlio de Santa Ana se refere aos "espíritos lúcidos" dessa época em meio aos conflitos que dilaceravam os cristãos europeus. Segundo o autor, uma destas iniciativas foi encabeçada pelo físico e matemático luterano Gottfried Wilhelm Leibniz (1646-1716), que ajudou a situar o termo no contexto moderno:

Profundamente escandalizado com o antitestemunho dessas guerras nas quais os cristãos, para defender a sua versão do Evangelho, estavam de fato sendo infiéis a ele, Leibniz enfatizou a necessidade de se chegar a construir uma Igreja Universal que desse lugar em seu seio às diferentes expressões da vida e da fé cristã. A partir de 1691 manteve contato epistolar com Bossuet, Bispo de Meaux e tutor da coroa da França. Foi através desta correspondência que a palavra ecumênico chegou a adquirir sua dimensão religiosa como indicação da universalidade do Cristianismo e, portanto, da própria fé e da Igreja de Cristo. ${ }^{14}$

Damos, então, um salto para o século XX, quando, após séculos que implicaram, inclusive, descrédito e discussões a respeito do Cristianismo e até da necessidade de religiões (com eventos como a Revolução Francesa e pensadores como Marx e Freud), o termo ganhou força renovada a partir de organizações cristãs de viés dialógico. A ideia, então, era a de reconstrução de pontes para a retomada da "casa comum".

Segundo Zwinglio M. Dias, ${ }^{15}$ na década de trinta do século passado os movimentos compostos pela Conferência Mundial do Cristianismo Prático (Movimento de Vida e Ação), pela Comissão de Fé e Ordem, pela Aliança Mundial para a Amizade Internacional Através das Igrejas, pela Associação Cristã de Moços(as) e pela Federação Mundial de Estudantes Cristãos expressaram seu desejo de integrar um único organismo.

Ocorreram, então, alguns fatos relevantes: o Movimento de Vida e Trabalho e a Aliança para a Amizade Internacional passaram a ter um único secretário-geral (1932); o Movimento de Vida e Trabalho propôs à Comissão de Fé e Ordem a criação de um grupo especial que fizesse a ponte entre ambos os movimentos (1933); a Comissão de Fé e Ordem se reuniu em Edimburgo e

${ }^{14}$ SANTA ANA, 1987 apud DIAS, Z. M., O Movimento Ecumênico, p. 133.

${ }^{15}$ DIAS, Z. M., O Movimento Ecumênico, p. 139. 
o Movimento de Vida e Ação se reuniu em Oxford. Em 1937, ambas as conferências trataram da criação de um Conselho Mundial de Igrejas - CMI. Em Utrech, na Holanda, preparou-se as bases constitucionais para a formação de um "Conselho Ecumênico de Igrejas" (1938). Curiosamente ou não, esse movimento ecumênico rumo à unidade se deu em um momento crítico do ponto de vista geopolítico: a ascensão do nazismo e do fascismo, o pós "crack da Bolsa" (de 1929) e a consolidação da URSS sob Stálin.

Esse período, denominado por alguns estudiosos de "Preparatório", teve longa duração por conta do início da Segunda Guerra Mundial. E, finalmente, em 1946, foi fundado o Instituto Ecumênico de Bossey (Genebra, Suíça). Em seguida, dois anos depois, em 1948 os três movimentos reuniram-se em assembleia em Amsterdã e decidiram pela criação definitiva do CMI (Fig. 04).

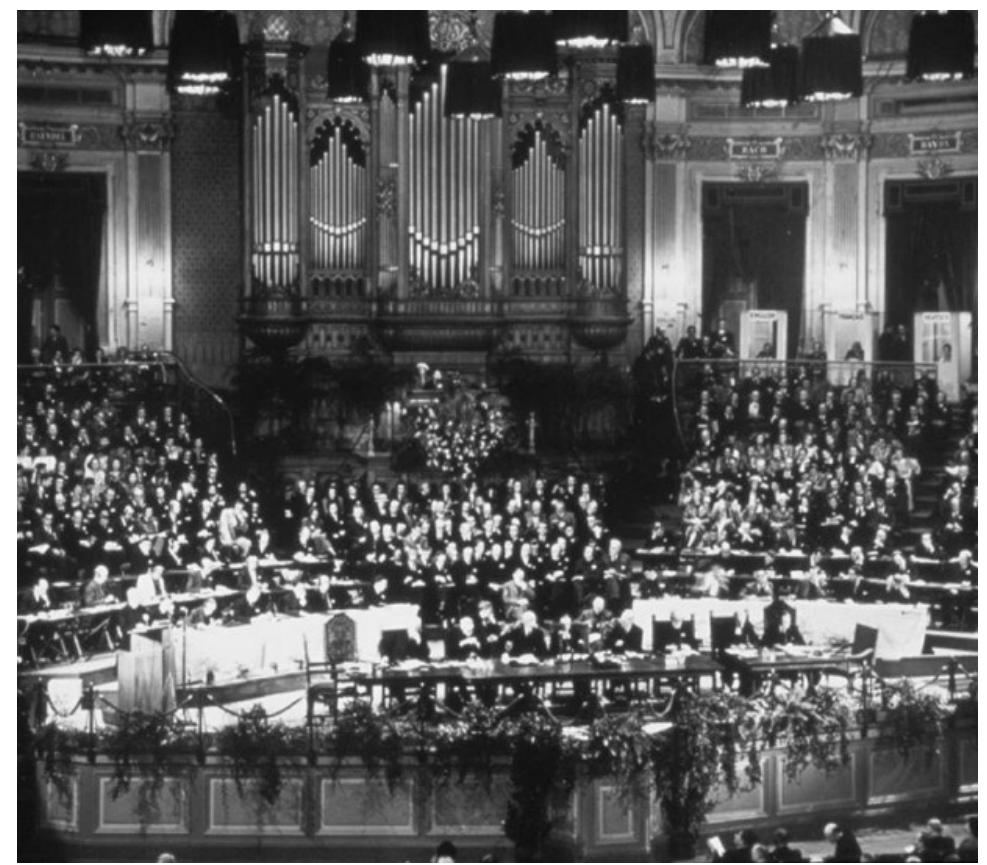

Figura 04 - Cerimônia de criação do Conselho Mundial de Igreja, Amsterdã, 23 de agosto de 1948 (PORTAL LUTERANOS) 


\section{Caminhos do ecumenismo no Brasil}

Segundo Wolff, ${ }^{16}$ há três grandes momentos do ecumenismo no Brasil: o primeiro que é exclusivamente interprotestante (1903-1960); o segundo, com a participação de católicos e anglicanos (1960-1982); e o terceiro, a partir da formação do Conselho Nacional de Igrejas Cristãs do Brasil - CONIC, em 1982.

$\mathrm{O}$ autor enfatiza que o movimento ecumênico no Brasil teve os missionários protestantes como protagonistas e caracteriza-se pelos seguintes elementos: acentuação da herança comum protestante (como as orientações dos reformadores e a ênfase na conversão pessoal), a unificação dos projetos de evangelização e a oposição ao catolicismo romano. ${ }^{17}$

Há, na história do ecumenismo brasileiro, três fatos importantes que merecem destaque. Eles são apontados por Elias Wolff como a "primeira fase" da história do movimento ecumênico brasileiro: o surgimento da Aliança Evangélica Brasileira - AEB (1903); da Comissão Brasileira de Cooperação CBC (1920) e da Confederação Evangélica Brasileira - CEB (1934). ${ }^{18}$

A Aliança Evangélica Brasileira foi fundada em São Paulo em julho de 1903, sendo a primeira entidade ecumênica no Brasil. Seu inspirador foi o metodista norte-americano Hugh Clarence Tucker (1857-1956). Seus objetivos eram lutar contra o papismo, promover os interesses do cristianismo escriturístico e descobrir um denominador doutrinário comum aos cristãos evangélicos.

A fundação da Aliança coincide com os dez anos da separação entre Igreja e Estado no Brasil, com a primeira Constituição republicana. Já nessa época, a Igreja Católica Romana, desvestida da antiga aliança imperial, buscava tentativas de união com os evangélicos.

Mas, segundo Wolff, ${ }^{19}$ naquele momento era quase que impensável uma unidade, fosse por razões históricas - pela primeira vez, as igrejas protestantes estavam se lançando no mercado religioso brasileiro como movimentos aceitos pela lei -, fosse por questões de viés doutrinário.

Entretanto, essa busca por uma unidade resultou, dentro do contexto protestante, na fundação das Escolas Dominicais. Primeira associação do gênero em todo o Brasil, em 1918 foi transformada no Conselho Evangélico de

\footnotetext{
${ }^{16}$ WOLFF, E., Caminhos do Ecumenismo no Brasil, p. 91.

${ }^{17}$ WOLFF, E., Caminhos do Ecumenismo no Brasil, p. 91.

${ }^{18}$ WOLFF, E., Caminhos do Ecumenismo no Brasil, p. 91.

${ }^{19}$ WOLFF, E., Caminhos do Ecumenismo no Brasil, p. 91.
} 
Educação Religiosa no Brasil. Para Wolff, ${ }^{20}$ um dos seus limites era ser formada pela maioria de membros do protestantismo missionário.

\subsection{Principais frutos do congresso no Panamá para o Brasil}

Wolff ressalta a importância da realização do Congresso do Panamá, realizado em 1916, e de sua importância para o Ecumenismo no Brasil. ${ }^{21}$ A partir desse evento fortaleceram-se os planos da Aliança Evangélica Brasileira - AEB, com a finalidade de elaborar lições comuns para a escola dominical e unificar as imprensas e os estoques de livros no Rio de Janeiro.

No mesmo ano, realizou-se, também, a Primeira Conferência Evangélica Brasileira (14 a 18 de abril), na Igreja Presbiteriana do Rio de Janeiro. Em 1918, foi criada a Comissão Brasileira de Cooperação - $\mathrm{CBC}$, cujas atividades iniciaram-se dois anos depois, em 1920, tendo como primeiro presidente o líder presbiteriano Erasmo Braga.

Nos anos 30, as iniciativas ecumênicas tomaram força na América Latina, principalmente após a realização dos congressos continentais de Montevidéu (1925) e Havana (1929). Tais eventos influenciaram os esforços pela unidade.

\subsubsection{Abertura das fronteiras ecumênicas}

Wolff ${ }^{22}$ assevera que o movimento ecumênico no Brasil se expandiu a partir de 1950 graças à intensificação da ação de seus integrantes. O diálogo não ocorre apenas no interior do protestantismo missionário, mas, também com luteranos, anglicanos, com o Conselho Mundial de Igrejas e, inclusive, com membros da Igreja Católica Romana.

Nos anos 1960, a Igreja metodista cria estruturas que lhe permitem desenvolver o espírito ecumênico, como a Comissão Ecumênica Intereclesiástica, criada com o Concílio Vaticano II (1962-1965). O Vaticano II propôs uma renovação do catolicismo, em sua Teologia, suas estruturas, sua ação pastoral. O ecumenismo colocava-se, também como causa e consequência da renovação em várias esferas da Igreja:

\footnotetext{
${ }^{20}$ WOLFF, E., Caminhos do Ecumenismo no Brasil, p. 91.

${ }^{21}$ WOLFF, E., Caminhos do Ecumenismo no Brasil, p. 91.

${ }^{22}$ WOLFF, E., Caminhos do Ecumenismo no Brasil, p. 91.
} 
Esta renovação tem, por isso, grande importância ecumênica. Ela já é efectuada em várias esferas da Igreja. Tais são os movimentos bíblico e litúrgico, a pregação da palavra de Deus e a catequese, o apostolado dos leigos, as novas formas de vida religiosa, a espiritualidade do matrimónio, a doutrina e actividade da Igreja no campo social. Tudo isto deve ser tido como penhor e auspicio que felizmente prognosticam os futuros progressos do ecumenismo. ${ }^{23}$

"O Concílio foi um ato ecumênico em si mesmo e não é possível compreendê-lo sem considerar esse fato". ${ }^{24}$ E o ecumenismo, a partir do Concílio, tornou-se uma forte expressão de muitos cristãos católicos.

Existe, portanto, uma intrínseca relação entre Concílio Vaticano II e ecumenismo, o que permite afirmar que somente onde o Concílio foi assumido de modo efetivo é que o ecumenismo ganhou espaço no jeito de a Igreja Católica ser e agir. Ali, houve abertura para o diálogo com as diferentes tradições eclesiais, religiosas e culturais, tanto no âmbito local quanto no âmbito universal.

O clima do Concílio do Vaticano II leva líderes de outras igrejas cristãs a se aproximarem dos católicos romanos. Reconhecendo as transformações ocorridas na Igreja Católica após o Concílio Vaticano II, os bispos metodistas vão afirmar que:

Incorrerá em erro grave quem julgar a Igreja Católica Romana atual à luz do catolicismo medieval, isso porque "força é reconhecer que nas atitudes com os outros ramos do cristianismo [...]. A mudança foi grande na Igreja Romana". ${ }^{25}$

Segundo o autor, o Brasil também estava em sintonia com o movimento ecumênico continental. Pois importantes eventos estavam relacionados com o movimento ecumênico brasileiro, tais como a criação da Organização Igreja e Sociedade na América Latina (ISAL), durante a consulta Igreja e Sociedade realizada em Huampani (Peru), em julho de 1961, além da Unidade Evangélica Latino Americana - UNELAM, criada em 1965 na Assembleia dos Conselhos Ecumênicos, em Campinas. Além de outra iniciativa muito importante abordada por Elias, a do movimento de jovens. ${ }^{26}$

\footnotetext{
${ }^{23}$ UR 6.

${ }^{24}$ WOLFF, E., Caminhos do Ecumenismo no Brasil, p. 404.

${ }^{25}$ WOLFF, E., Caminhos do Ecumenismo no Brasil, p. 91.

${ }^{26}$ WOLFF, E., Caminhos do Ecumenismo no Brasil, p. 92.
} 
A consolidação do movimento ecumênico no Brasil aconteceu com a criação do Conselho Nacional de Igrejas Cristãs - CONIC, em 1982. A partir de então, definiu-se a metodologia e estrutura do movimento. Tal estrutura está atrelada a três modelos de atuação: o diálogo teológico e pastoral, o diálogo igreja-igreja e o diálogo igrejas-sociedade. ${ }^{27}$

\section{Conclusão}

No presente artigo, nos dispusemos a apresentar uma trajetória sintética do ecumenismo, de sua concepção etimológica à sua chegada, no contexto institucional cristão, ao Brasil. Para tanto, fizemos uma leitura do tema a partir de alguns autores relevantes no campo - como Elias Wolff, Zwinglio M. Dias e Julio de Santa Ana - e apontamos algumas reflexões que são fruto desta revisão bibliográfica.

Este artigo também é fruto das aulas, das conversas e trabalhos apresentados em sala de aula. Mas, cabe frisar, especialmente pelas leituras realizadas para a apresentação de um seminário com o mesmo tema. Dessa forma, ressalto que, para a autora, trata-se de um tema novo e com um caminho ainda a percorrer. Alguns elementos importantes foram apontados neste artigo com a intenção de suscitar futuras pesquisas.

De toda forma, a intenção foi esboçar um entendimento histórico acerca do ecumenismo ou, minimamente, construir algumas reflexões a respeito do tema.

\section{Referências bibliográficas}

BÍBLIA da mulher de fé. Rio de Janeiro: Thomas Nelson Brasil, 2016.

CONCÍLIO VATICANO II. Decreto Unitatis Redintegratio sobre o Ecumenismo. Vaticano, $1964 . \quad$ Disponível em: $<$ http://www.vatican.va/archive/hist_councils/ii_vatican_council/documents/vat -ii_decree_19641121_unitatis-redintegratio_po.html>. Acesso em: 28 jun. 2020.

CRANACH, L. Retratos de Martinho Lutero (1483-1546) e Phillipi Melanchton (1497-1560). 1558. 1 original de arte, óleo sobre tela, $88.6 \mathrm{~cm} \mathrm{x}$ $61.3 \mathrm{~cm}$. Coleção Museu de Arte da Carolina do Norte.

DIAS, Z. M. O Movimento Ecumênico: história e significado. Numen, v. 1, n. 1, p. 127-163, 1998.

${ }^{27}$ WOLFF, E., Caminhos do Ecumenismo no Brasil, p. 128. 
HORIZONTE - Revista de Estudos de Teologia e Ciências da Religião (PUC Minas), Dossiê "Lutero e a Reforma: 500 anos", v. 14, n. 44, out./dez. 2016. Disponível em: <https://bit.ly/3wCyUE0>. Acesso em: 11 nov. 2021.

JAVIERRE, A. La Unión de las Iglesias. Ciudad de Guatemala: Instituto Teológico Salesiano, 1977.

NAVARRO, J. B. Para compreender o Ecumenismo. São Paulo: Loyola, 1995. PORTAL LUTERANOS. 70 Anos do Conselho Mundial de Igrejas (CMI), 23 ago. 2018. Disponível em: $<$ https://www.luteranos.com.br/textos/70-anosdo-conselho-mundial-de-igrejas-cmi> . Acesso em: 01 set. 2021.

TEOCOMUNICAÇÃO (PUCRS), Dossiê "500 anos da Reforma Luterana: heranças e desafios", v. 49, n. 1, jan./jun. 2019. Disponível em: $<$ https://bit.ly/2YGCKzA>. Acesso em: 11 nov. 2021.

WIKIPÉDIA. Arte sobre mapa da Europa e Ásia Menor. Disponível em Wikipedia: <https://bit.ly/3mUc9ZC >. Acesso em: 01 set. 2020.

WIKIPÉDIA. Uma representação moderna do 'ecúmeno' descrito por Heródoto no século V a.C. Possivelmente como era o mundo de acordo com Heródoto (século 5 a.C.). Disponível em: $<$ https://en.wikipedia.org/wiki/Ecumene\#/media/File:Herodotus_world_mapen.svg>. Acesso em: 28 jun. 2020.

WOLFF, E. Caminhos do Ecumenismo no Brasil: História, Teologia, Pastoral. São Paulo: Paulos, 2001.

Daniele Rocha Saucedo Mestre em História pela Universidade Federal do Paraná Docente na Escola de Educação e Humanidades da Pontifícia Universidade Católica do Paraná Curitiba / PR - Brasil E-mail: daniele.saucedo@pucpr.br

Recebido em: 31/08/2020 Aprovado em: 10/12/2021 